\title{
CHRISTOLOGY AND THE SYNOPTIC PROBLEM 1
}

\section{Peter M. Head}

The primary aim of this dissertation has been to examine and evaluate the christological argument for Markan priority in view of recent scholarship on the synoptic problem which advocates Markan posteriority (normally as part of the Griesbach Hypothesis, henceforth GH).

Chapter One contains an overview of the history of discussion, with a particular focus on the relationship between christological development and literary priority (evident in both nineteenth-century Griesbachians and twentieth-century Markan Priorists). The christological argument for Markan priority emerged within British scholarship as a means of defending Markan priority and explaining Matthean alterations of Mark. Although this particular argument has played a relatively small role in supporting the structure of the two source hypothesis $(2 \mathrm{SH})$, several factors suggest its contemporary importance and the need for a critical assessment. The most important of these factors is the revival of the GH, which has involved criticisms of the arguments used to support the $2 \mathrm{SH}$. These criticisms have, in turn, prompted from Markan priorists a re-assessment of the arguments from wording, order and content. Within this context it seemed appropriate and necessary to reassess arguments from christological development, a notion that was also appealed to by nineteenth-century defenders of the GH.

In Chapter two, after a survey of proposed criteria for determining literary priority, we argue that a method which focuses on redactional plausibility and coherence is both

\footnotetext{
1P.M. Head, Christology and the Synoptic Problem: An Assessment of one Argument for Markan Priority (Unpublished Ph.D. Thesis, University of Cambridge, 1994); supervisor: Prof. M.D. Hooker.
} 
appropriate to the christological material in view and able to treat the two major hypotheses in a relatively even-handed manner. Thus the discussions of the texts involve a comparison between the plausibility of Markan redaction, assuming the $\mathrm{GH}$, and the plausibility of Matthean redaction, assuming the $2 \mathrm{SH}$. Any alternative method would involve the assumption of a particular pattern of christological development within the early period. Our method, however, focuses on the texts we do have, rather than the pattern of development which we do not have. It also allows both hypotheses to be tested in relation to their treatment of christologically-loaded material. It allows this dissertation to test both whether the traditional argument should be regarded as a strong support for Markan priority, and whether the $\mathrm{GH}$ might be able to give a more plausible picture of redactional behaviour. Thus the two major hypotheses (2SH and $\mathrm{GH})$ are compared in order to assess which provides the best explanation (in a comparativeredactional sense) of the evidence.

The investigation proper takes as its Ausgangspunkt two passages which were at the heart of the historical christological argument (described in chapter one). We compare the $2 \mathrm{SH}$ perspective and then the $\mathrm{GH}$ perspective on the passages concerning: the rich young ruler (Chapter Three) and Jesus' rejection at Nazareth (Chapter Four); and then the walking on water (Chapter Five). This investigation suggests that the commonly held view that Matthew avoids christologically embarrassing phrases does not provide a sufficient explanation of Matthean redactional behaviour. Nevertheless, the $2 \mathrm{SH}$ is able to provide (at least for two of the three passages) a more plausible and coherent explanation than the GH.

Chapter Six deals with the issues of Jesus' emotions, questions, and inability (highlighted in chapter one) which all involve (on the 2SH) Matthean omissions from Mark. Chapter Seven deals with other areas of the Matthean redaction which have been claimed as a support for Markan priority ('worship' and 'approach' terminology and the passion narratives), which all involve Matthean additions to Mark. The focus in these chapters is to test this material in order to evaluate the claims 
of Markan priorists. In many cases the GH explanation is found to be equally plausible (e.g. on the passion narratives), and the christological interests of Matthew have been exaggerated (e.g. on 'worship' and 'approach' terminology). This conclusion leads to the following chapters in which an attempt is made to compare the evangelists' treatment of major christological themes, using the christological titles as convenient loci for study.

In Chapter Eight we argue that the $2 \mathrm{SH}$ makes much better sense of the treatments of Jesus as teacher and as Lord than does the $\mathrm{GH}$. Matthean redaction of Mark (on the 2SH) can be described as both coherent and plausible on several levels, especially in relation to the OT, in a way that could not be said of Griesbach-Mark. In Chapter Nine we again conclude, concerning the presentation of Jesus as Messiah, that the redactional activity of Matthew envisaged by the $2 \mathrm{SH}$ is both coherent and pervasive and plausibly understood as a reappropriation of Jewish and OT categories for Matthew's situation.

In Chapter Ten we investigate the treatment of Jesus as the Son of God. In this case several specific problems are noted in relation to the redactional procedure of GriesbachMark which are not present in Matthew's redaction of Mark $(2 \mathrm{SH})$. A similar conclusion is drawn from the Son of Man material (Chapter Eleven). In both cases Matthew's redaction of Mark involves an increased appropriation of OT allusions in service of the tradition.

These chapters form the basis, therefore, for a renewed christological argument for Markan priority, based not on what Matthew omitted from Mark, but on the coherent, plausible, pervasive and positive redactional alterations made by Matthew in his re-presentation of the Markan traditions. In several places, however, the redactional activity envisaged for Griesbach-Mark could be construed in terms of a developed but previously misconstrued secrecy motif. It therefore proves necessary to investigate the secrecy material with a view to assessing whether this material can be more plausibly explained by the GH (Chapter Twelve). We conclude, however, that this material does not offer a key which would 
explain Griesbach-Mark; on the other hand the 2SH generally offers a reasonable and coherent picture of Matthean redaction activity in this area.

The Conclusion summarises the course of the discussion and offers three major conclusions: i) that the christological argument as traditionally conceived does not offer a compelling argument for Markan priority; ii) that the $\mathrm{GH}$ is generally unable to provide a plausible explanation for the behaviour of Griesbach-Mark in this area; and iii) that a re-formulated christological argument focusing on the positive christological emphases of Matthew is a powerful argument in favour of the $2 \mathrm{SH}$ over the $\mathrm{GH}$. 